\title{
Discourse of civil military relations in Nepal
}

\section{Chiranjibi Bhandari Rajendra Sharma}

\section{Abstract}

A sovereign nation -state requires a strong military institution and the Nepali Army demands its personnel's obedience, loyalty, sacrifice and discipline to maintain command and control. However, as an established principle, civilian control of the military is desirable to the military control of the state. The concept of Civil Military Relations (CMR) is dynamic, evolutionary and country specific. Such a bond between an official security organization and the public in general change with regime shifts, external imperatives and technological innovations. The impact of regime changes and political movements has been observed in various aspects of politics, society in Nepal is not an exception. In this line, this article deals on the theoretical discourse of CMR, reviews the constitutional and legal provisions and examines the factors influencing CMR in Nepal from the period of modern nationstate formation to present days. Along with existing debates around the role of the Nepali Army in various non-military jobs, this paper proposes multiple perspectives on how different entities, including bureaucrats, politicians and military leaders perceive CMR. Likewise, the writers argue that sharing the responsibilities among the civil society, citizenry and military organizations is one of the most suitable approaches in response to balancing CMR in Nepal.
\end{abstract}

Keywords: civil military relations, the Nepali Army, regime change, nation-state, dynamics

\section{Introduction}

It was commonly believed that the state army was established prior to the unification of Nepal. King Prithivi Narayan (P.N.) Shah, the founder of modern Nepali nation-state, had played a significant role in the establishment of the military and the modern Nepal and named the army as 'Tilanga'. It was changed to the 'Gorkhali Army' after the Gorkha conquest of Nuwakot. Chandra Shumsher named it 'Nepal Army' and the title "Royal Army' was given by King Mahendra, later on King Birendra named it as 'Royal Nepal Army' (Acharya, 2009, p. 128). It was renamed 'Nepal Army' after the proclamation of the House of Representatives (HoR), on 18 May 2006 (ASPECT, 2011, p. 8).

Besides King, civilian leaders like Bhimsen Thapa (1775-1839) and Jung Bahadur Rana (1816-1877) have made significant contribution to modernize of the Nepali Army. Mukhtiyar Thapa took remarkable measures to advance the military administration and institutional organization. The Lal-Dhadda, the systematic maintenance of military records, was initiated under his instruction. Then Prime Minister Thapa also developed a classified military organization with designations, adding the post of General and Colonel (Adhikari, 2015, p. 102).The Prime 
Minister and Commander-in-Chief Jung Bahadur Rana (1846-1856) and (1857-1877) placed all the male members of his family on the rolls with military titles and the rank of Lieutenant Colonel. He further introduced a rank of Lieutenant-Colonel and adopted a more inclusive recruitment policy (Adhikari, 2015, p. 108).

Interestingly, after each political change, the Nepali Army was forced to transform to cope with the aspirations of the political changes and leaderships in the military. In the 1950s, the Nepali Congress-led struggle was concluded with the tripartite agreement among the Ranas, the pro-democratic force led by Nepali Congress and the King that was mediated by India. However, the military was then downsized in a process of modernization of the Nepali Army upon the recommendation of the Indian military mission (Basnyat, 2018, p. 48).

In 1960, then King Mahendra Shah imposed a state of emergency, which outlawed political parties and dissolved the parliament in the backing of Royal Nepal Army (RNA). The Party-less Panchayat system continued till the 1990. With restoration of democracy in 1990 , the country became a multi-lingual, multiethnic but a Hindu state and Constitutional Monarchy remained unchanged in the Constitution of Nepal (1990). In 1996, six years after the restoration of the democracy, country entered into an armed conflict, led by then Communist Party of Nepal-CPN (Maoist). The Royal massacre of 2001 and the king's direct rule (2004-2005) contributed to weaken the faith of Nepalese citizens on monarchy and nurtured the synergy between the then mainstream political parties: Seven Parties Alliances (SPA) and the Maoist.
The 12-point understanding, between then mainstream political parties and then CPN (Maoist) signed in India on 22 November 2005 paved the way to the Comprehensive Peace Accord 2006 along with subsequent political agreements. The Communist Party of Nepal-CPN (Maoist)'s with 220 out of 575 seats, became the largest party in the Constituent Assembly Election I of 2008. The Maoist-led incumbent Government created turmoil in the Civil-Military Relations in Nepal. Then Prime Minister Puspa Kamal Dahal's move to sack the Chief of the Army Staff (COAS) Rookmangud Katuwal and the President's intervention against the elected Prime Minister's decision unfolded a new discourse in the Civil-Military Relations in Nepal. The Constituent Assembly II promulgated the constitution in September 2015. The successful completion of three tiers of election in 2017 and practices of three forms of government at federal, provincial and local level further unraveled the discourse in CMR in Nepal.

In this background, this article briefly examines the discourse of the CivilMilitary Relations, its constitutional and legal provision in Nepal along with factors influencing this bond during the different regimes. This article is based on both primary and secondary data from different sources. For the primary information, interview were taken with 20 key individuals, including military personnel and civilian. Various resource materials, such as books, articles and newspapers stories were used as the source of secondary information.

\section{Discourses of CMR}

CMR is an interaction between the armed forces of a state as an institution, and the other sectors of the society the armed force 
is rooted in. It is perceived as power sharing between the legitimate civil authority of a state and its security forces (Sharma \& Thapa, 2010, p. 970), encompassing the entire range of relationship between military and civilian society (Feaver, 2003, p. 54). Theoretically, the security forces in the countries with liberal democracies are placed under the command of the civil government, carry out orders and are accountable to it. The evolution of CMR discourse dates back to 1950 s. Institutional theory remains the dominant paradigm for examining civilmilitary relations (Huntington, 1957, pp. 8183). As civilian control of the military, Samuel P. Huntington's subjective and objective control of the military seems antithetical with themselves. Peter Feaver's agency theory stands on different position in Huntington's notions of CMR. In objective civilian control, Huntington had prescribed for autonomous, apolitical, neutral professional military, which is not possible in liberal democracy (Feaver, 2003, pp. 16-18).

As alternative to Huntington's institutional set up, Michael C. Desch described 'structural environment' as determinant for military organization (Desch, 2001, pp. 8-21). In The Professional Soldier, Morris Janowitz argues for the civilianization of the military by converging civilian and the military society. Janowitz further claims that distinction between the civilian and military roles (Janowitz, 1960, p. I) that lay at the heart of Huntington's theory had been blurred by the emergence of nuclear weapons and limited war. As an alternative, Rebecca L. Schiff offers a new theory-Concordance - in the Civil-Military Relations. The concordance theory has an argument in a similar line with a proposition of the partnership within a polity-the military, the political elite, and the citizenry-on four issues; the social composition of officer corps, the political decision-making process, the method of recruiting soldiers, and military style (Schiff, 2001, pp. 32-33).

Also, the rising ethno-national civil wars after the end of Cold War (1945-89) on the one hand and the internationalization of the military as peace keeping force on the other hand, 'who controls who' in the thesis of civil-military relations is itself problematic. It was clearly proposed to share roles and responsibilities among civilians and the military society for an effective Civil Military Relations (Bland, 1999, pp. 7-26). Similarly, in order to cover the full scope of CMR, six interdependent and interpenetrated dimensions have been proposed including economy, finance, technology, culture, society and politics (Kummel, 2002, p. 69). Therefore, the extent to which the civilian authorities actually exercise control on the military differs based on characters of states as well as forms of the regime.

\section{Constitutional and legal provisions related to CMR}

The history of documented legal provisions for CMR is fairly short in Nepal. It started in the late eighteenth century with Dibya Upadesh (Nepal Law Commission, 2018, p. 9). Dibya Upadesh prescribed certain privileges and incentives to the military and clearly differentiated the military and civilian spheres, valorizing the importance of the military in Nepal. Prominently, monarchy had played a key role in establishing the Army as well as national security related issues from the unification to 1990s. For instance, even after the 1950s political change with the fall of the Rana regime along with the transfer of the Bijuli Garat, guns and ammunitions from 
Singha Durbar (the residence of Rana Prime Minister) to the Narayanhiti Durbar (the residence of the King), the Army forces also shifted their loyalty back to the monarchy and King Tribhuvan assumed the title of Supreme-Commander in Chief in April 1952 (Kumar, 2009, p. 140).

During the Panchayat regime (1960-1990), the relationship between the Army and the King was further consolidated with the adoption of the Military Act in 1959. It was further deepened with the Act on Right, Duty, Function and Terms of the Service of Commander-in- Chief 1969' made the Chief of the Army Staff (COAS) responsible and accountable to His Majesty (Kumar, 2009, p. 140). The Military Act 1959 was amended for the first time after a long gap in September 2006 that unties the embryological cord of the Army with the King. One of the key features of the amendment was the severing of age old ties between the Army and the King. Except for this, the amendment introduced no major changes in the structureor functions of the Army (Sharma and Thapa, 2010, p. 991). In new Military Act, chapter 3, 'It mainly focuses on fiddling with the term of office of senior officials. ${ }^{1}$ The 2006 amendments limit to four years, which could be extended once for another three years' (Government of Nepal, 2006, p. 10).

1 For example, the 1959 Act provided for the General's term of office fixed at five years, which could be extended first time for three years, then if necessary for another two years (Ibid). This way a General of the Army could stay in office for 10 years.

\begin{tabular}{|c|c|c|}
\hline $\begin{array}{l}\text { S. } \\
\text { N. }\end{array}$ & Documents & $\begin{array}{l}\text { Introduced/Enacted/ } \\
\text { Promulgated by }\end{array}$ \\
\hline 1. & $\begin{array}{l}\text { Dibya } \\
\text { Upadesh }\end{array}$ & $\begin{array}{l}\text { King P. N. Shah } \\
(1742-1774)\end{array}$ \\
\hline 2. & $\begin{array}{l}\text { JangiAin } \\
\text { (Military } \\
\text { Law) }\end{array}$ & $\begin{array}{l}\text { PM Jung Bahadur } \\
\text { Rana, } 1854\end{array}$ \\
\hline 3. & Military Ain & $\begin{array}{l}\text { Interim Government, } \\
1951\end{array}$ \\
\hline 4. & Military Act & King Mahendra, 1959 \\
\hline 5. & Constitution & King Mahendra, 1959 \\
\hline 6. & $\begin{array}{l}\text { Act on } \\
\text { Right, Duty, } \\
\text { Function and } \\
\text { Terms of the } \\
\text { Service of } \\
\text { Commander- } \\
\text { in- Chief }\end{array}$ & King Mahendra, 1959 \\
\hline 7. & $\begin{array}{l}\text { Constitution } \\
\text { of } 1990\end{array}$ & $\begin{array}{l}\text { Constitution Drafting } \\
\text { Committee, } 1990\end{array}$ \\
\hline 8. & Military Act & $\begin{array}{l}\text { Reinstated Parliament, } \\
2006\end{array}$ \\
\hline 9. & $\begin{array}{l}\text { Interim } \\
\text { Constitution }\end{array}$ & $\begin{array}{l}\text { Reinstated Parliament, } \\
2006\end{array}$ \\
\hline 10. & $\begin{array}{l}\text { Constitution } \\
\text { of Nepal } 2015\end{array}$ & $\begin{array}{l}\text { Constituent Assembly, } \\
2015\end{array}$ \\
\hline 11. & $\begin{array}{l}\text { National } \\
\text { Security } \\
\text { Policy }\end{array}$ & $\begin{array}{l}\text { Government of Nepal, } \\
2016\end{array}$ \\
\hline 12. & $\begin{array}{l}\text { National } \\
\text { Security } \\
\text { Policy }\end{array}$ & $\begin{array}{l}\text { Government of Nepal, } \\
2019 \text { (Unpublished) }\end{array}$ \\
\hline
\end{tabular}

Source: Compiled from various sources by the authors

The Constitution of Nepal (1990), article 118 and 119 provisioned that the King, as the Supreme Commander of the Army, would mobilize the troops as per the recommendation of the three-member National Defense Council (NDC) consisting of the Prime Minister, the Defense Minister 
and the Army Chief (p. 51). Until 2005, the regime projected the King as a symbol of the national unity, and any threat to institution would ultimately means a threat to the security of the nation. Whatever directives the palace decided were taken as guiding principles for the Army on security issues, and whatever policy the Army declared was considered to be national security policy (Wagle, 2009, p. 76). The security and the military landscapes remain unchanged; however, national security was still the exclusive domain of the place and the elected government followed the same traditional security policy (Wagle, 2009, p. 77).

After the political change of 2006, Nepal's security system saw paradigm shifts. These significant changes include the historical proclamation of the then reinstated House of Representatives on 18 May 2006 and incorporation of the spirit of peace agreements in the Interim Constitution (IC) of 2007; the armed forces automatically came under democratic control (UNDP, 2009, pp. 228-230). Similarly, IC had a robust provision for an action plan for acts of right sizing the Nepali Army, building its democratic structures, national and inclusive character and imparting training to the Army in accordance with the values of democracy and human rights (ibid).'Article 144 also incorporated the provisions regarding the President as Supreme Commander of the Army with an authority of appointing the COAS, controlling, mobilizing and managing the Army on the recommendation of the Council of Ministers (fourth amendment of Interim Constitution, 2007). The fifth amendment of IC introduced the provisions as 'in order to give the Nepali Army a national Character and make it inclusive, enlisting of Madhesi, indigenous ethnic groups, Dalits, women, and people from backward regions into the armed forces on the basis of the principles of equality and inclusiveness shall be insured by laws' (Article 4A) (UNDP, 2009, p. 37).

The IC (2007) had provision of an expanded National Defense Council (NDC) with Prime Minister as chairperson, and Defense Minister, Home Minister and three nominees of the Prime Minister as member (Article 145) (UNDP, 2009, p. 230). Interestingly, the Interim Constitution 2007 paid less attention to the roles and functions of the armed forces. Focused mainly on how they are controlled, mobilized and managed and how the COAS would be appointed. Nowhere did it deal with the fact that the primary objectives of the armed forces are to defend and protect the country, its citizens and its territorial integrity in accordance with principle of international law regulating the use of forces (Kumar, 2009, p. 149). Instead, the Constitution had given responsibility to prepare a comprehensive program for the democratization of the Nepali Army on the basis of political consensus to the Council of Ministers and then recommendation to the parliament (in National Gazette 2007 as cited in Kumar, 2009, pp. 145-150).

In Constitution of Nepal 2015, part 28 is related with 'provision related to national security'. The article 266 deals with the provision related to the National Security Council (NSC). The provisions of NSCis further clearer than the provision of NDC in Constitution of Nepal 1990. The objective of NSC is being extended in the existing constitution, it can recommend to government for the formulation of a policy on overall national interest, security and defense, for mobilization and control of the Nepali Army it had to recommend to the Council of Ministers (Government of Nepal, 2015, p. 176). 
Principally, the National Security Policy has to be formulated by the National Security Council. In the context of Nepal, the government of Nepal had formed a committee headed by the then Defense Minister which designed and formulated the NSP in 2016. In order to adjust the federal set up, it was reported in media that the new security policy was enacted in 2019 as well, but this document was concealed until then. Despite its limitations in defining national goals, objectives and vital national interest intersect. It has different sections dealing with the roles and responsibilities of the law enforcement agencies in line with the Constitution of 2015. The NSP has not precisely mentioned CMR in any chapter. However, the terms civilian control of the military and civilian supremacy have been used in the policy (Government of Nepal, 2016, pp. 49-55).

\section{Different views on CMR}

The uncommon understanding on the roles and responsibilities, and acute skepticism among representatives of civilian and military was observed during the primary data collection process. For instance, bureaucrats shared that 'Government' as the custodian of the security organizations, whereas the Nepali Army upheld 'Constitution' as their guardian. The spokesperson of the Nepali Army shared his understanding, 'CMR means the relationship between the civilian authority and the military. ${ }^{2}$ Interestingly the spokesperson of the Armed Police Force, one and only paramilitary force in Nepal, viewed 'CMR is more related to the Army, this is not our concern and I don't have proper ideas on this regards ${ }^{3}$. However, the retired Assistant Inspector General from the Paramilitary

2 Interview on 4 November, 2018

3 Interview on 13 November, 2018
Force realized CMR as 'an instrument or framework that clearly defines the position of civilian, military and the government. We don't have any defined position about these actors's.

Also, the involvement of the Nepali army in infrastructures, construction of national pride projects, protecting forest, mines, conservation areas etc. are the indicators of good CMR for the spokesperson of the Ministry of Defense ${ }^{5}$. Whereas a former defense secretary only mentions that, 'CMR in Nepal's context deals with how civilian and the military treat each other'. Politicians from major political parties perceived CMR as a tool to control the military and stuck in rhetoric explanation of civilian control over the armed forces. However, experts in the field of security studies and CMR opined that CMR has lack of conceptual clarity in Nepal, and proposed the understanding of CMR as enhancing the performance of the military, military's recognition, increment of military's reputation.

It is visible that the understanding of the CMR among the civilian and the military is distinct. It is fair to highlight that the understanding of the CMR is distinct among the civilian and the military. The bureaucratic setup enjoys with 'civilian supremacy', politician with 'democratic principle and civilian control', and many more. By and large, it depicts that the Nepalese CMR is somehow familiar and affiliate with the aforementioned discussed Samuel P. Huntington's popular notion of 'Subjective Civilian Control' of military, which simply mean 'minimizing the military

4 Interview on 16 November, 2018

5 Interview on 21 November, 2018

6 Interview on 21 November, 2018 
power and maximizing of the power of civilian groups in relation to the military' (Huntington, 1957, p. 80).

Even in the international practices, the CMR is lunacy; it is contextual and varies from state to state. The degree of interplay between the civilian and military determines its equilibrium. These degrees were highly influenced by the understanding of the CMR itself. Based on these understanding, the civilian visualizes the legal and institutional set ups. These set ups in other are cemented by the international factors and the history of the military itself.

\section{Factors influencing CMR}

Theoretically, the functional CMR is the benchmark of a stable regime that balances military-civil polity and strength of national security. The robust patterns of the CMR in a particular country determine the stability of that country, and vice-versa. Therefore, it is important to focus on "who controls the military and how, degree of military influence in national and foreign policy, appropriate role of the military in a given polity, composition of the military, and impact of the societal structures on the military effectiveness. Below mentioned table provides brief overview of who controlled the military, and how, degree of military influences, role of military in given polity, who served in military and effectiveness of military instrument in different time period in Nepal.

\begin{tabular}{|c|c|c|c|c|c|c|c|c|}
\hline \multirow[t]{2}{*}{ Questions } & \multicolumn{8}{|c|}{ Regime-different time period } \\
\hline & $\begin{array}{c}\text { Unification } \\
1846\end{array}$ & $\begin{array}{l}1846- \\
1950\end{array}$ & \begin{tabular}{|l|}
$1950-1960$ \\
\end{tabular} & $\begin{array}{l}1960- \\
1990\end{array}$ & $\begin{array}{l}1990- \\
2001\end{array}$ & $2001-2005$ & $\begin{array}{l}2007- \\
2015\end{array}$ & $\begin{array}{c}2015 \\
\text { onwards }\end{array}$ \\
\hline $\begin{array}{l}\text { Who } \\
\text { controlled } \\
\text { the military, } \\
\text { and how? }\end{array}$ & $\begin{array}{l}\text { Monarch } \\
\text { (Shah } \\
\text { Kings) }\end{array}$ & $\begin{array}{l}\text { Rana PM } \\
\text { (Military } \\
\text { leader) }\end{array}$ & Monarch & & & & Civilian & Civilian \\
\hline $\begin{array}{l}\text { Degree of } \\
\text { Military } \\
\text { Influence in } \\
\text { Nepali } \\
\text { Society }\end{array}$ & High & High & Moderate & High & Moderate & $\begin{array}{l}\text { Moderate- } \\
\text { High }\end{array}$ & Moderate & Moderate \\
\hline $\begin{array}{l}\text { Role of the } \\
\text { military in a } \\
\text { given polity }\end{array}$ & $\begin{array}{l}\text { Royal } \\
\text { Decree }\end{array}$ & $\begin{array}{l}\text { Rana } \\
\text { PM's } \\
\text { Decree } \\
\end{array}$ & \begin{tabular}{|l|} 
Semi- \\
Constituti- \\
onal
\end{tabular} & Constit & utional & & & \\
\hline $\begin{array}{l}\text { Who served } \\
\text { (Primarily) } \\
\text { in military? }\end{array}$ & $\begin{array}{l}\text { Certain } \\
\text { families }\end{array}$ & $\begin{array}{l}\text { Shumsher } \\
\text { and } \\
\text { Rana Kin }\end{array}$ & $\begin{array}{l}\text { Individuals } \\
\text { hill caste an }\end{array}$ & $\begin{array}{l}\text { from } \mathrm{Sl} \\
\mathrm{d} \text { other }\end{array}$ & $\begin{array}{l}\text { ah, Rana, K } \\
\text { thnic grour }\end{array}$ & $\begin{array}{l}\text { shetri and } \\
\text { os }\end{array}$ & $\begin{array}{l}\text { Inclusive- } \\
\text { ness }\end{array}$ & $\begin{array}{l}\text { Inclusive- } \\
\text { ness }\end{array}$ \\
\hline $\begin{array}{l}\text { Effective- } \\
\text { ness of } \\
\text { Military? }\end{array}$ & $\begin{array}{l}\text { Highly } \\
\text { effective }\end{array}$ & $\begin{array}{l}\text { Highly } \\
\text { effective }\end{array}$ & Effective & & & & & \\
\hline
\end{tabular}

Source: The framework was customized from Mackubin Thomas Owens's Civil Military Relations. Oxford Research Encyclopedia, online publication date, 2017 
In addition to the information added in this table, it is important to discuss other factors influencing the CMR in Nepal. In the case of Nepal, Ministry of Defense is an important structure to facilitate the role of the Nepali Army. However, regarding the effectiveness of role of Ministry of Defense, questions have been posed time and again. Many of the analysts have dubbed that Nepal's defense ministry simply as a powerless 'post-box' for the Army, with real power and responsibilities of the ministry vested in and exercised by the Principal Military Secretariat (PMS) at the Royal Palace until mid-2006 (Sharma and Thapa, 2010, p. 985). The National Security Council can be a prop for balancing the democratic civil-military relations (Bruneau and Sakoda, 2009, p. 225) since it has an important role to play in terms of making security policy and analyzing security dynamics and challenges, as the research oriented policy making body of the government (Wagle, 2009, p. 85).

Past track records show that, the NSC in Nepal was not constituted even during most of the democratic period. It was finally constituted in 2001 when the armed conflict was at its height, but it didn't work as effectively and independently as it should have done as per the constitutional spirit. After NSC, the democratically elected representatives in a country's legislature have an important role in controlling the military; formulating defense legislation, policy, and budgets; and monitoring their implementation (Giraldo, 2006 , p. 34). It is widely accepted that with the parliamentary involvement and debates, civilian oversight becomes democratic oversight (Born, Fluri and Lunn, 2010, p. 5). In Article 64 of the 1990 Constitution of Nepal, parliamentary committee system was introduced in 1990. But in our practice, there is a lack of independent parliamentary committee on defense; the State Affairs Committee (SAC) which is equivalent to security committee oversees the multiple issues including the Prime Minister and Council of Ministers, Home Ministry, Defense Ministry, NA, Nepal Police, APF.

Beside these factors, the Nepali Army confronts with the military wing of the regime or political party (whether it is Mukti Sena of Nepali Congress, PLA of CPNMaoist). Army was deployed by different regimes to repress the movement inside the country. Later on the same faction, after getting the verdict of people, the government initiated working in line with the constitution. This is one of the psychologically diverge experience of the civilian and the military. For instance, the downsizing of the then Nepali Army after the political change of 1950 on the recommendation of the Indian Military Mission, the military personnel always have the susceptibility over the political masters. The post 2006 agendas in security such as the democratization, right sizing, national character in NA and the CoAS Katuwal Case of 2008 in particular are some of the examples of visible and invisible clashes of the civilian and the military culture.

As an established national institution, the Nepali Army deserves great respect, faith and trust from the civilians for its contribution to the process of nation building and public security. Leaders and public have invariably applauded the NA personnel's roles to protect lives and property from natural and manmade disasters, its contribution to the UN peacekeeping mission is always exemplary. However, the engagement of the NA in nonmilitary activities and its welfare fund has 
generated controversy in the public. After 2001, different regimes have made the NA more ambitious by granting lucrative nonmilitary programs and projects. For an instance, the government's permission to the NA to open a commercial bank, operate industries, setup companies, and lunchprojects in partnership with national and international companies (Adhikari, 2015, p. 242) has made the Nepali Army as a "corporate army". The recent commercialization of Tri-Chandra Military Hospital, issue of Tundikhel, and involvement in Fast Track road construction projects are some of the NA's engagements in recent years. The NA's involvements in such fields which are not necessarily related to security have become some issues for serious discussions and critical speculations. These issues are brought the NA to controversy on grounds of overstepping its core mandate of safeguarding territorial integrity, sovereignty, national unity and independence.

\section{Geo-strategic location: BRI and IPS}

Nepal's geostrategic location is sensitive. The Founder King Prithvi Narayan Shah had limited military as a defensive force, maintaining friendly relation with its two neighbors: India and China. He stated that 'Nepal is like a gourd between two rocks and advised to maintain a treaty of friendship with the Emperor of China and emphasized the significance of a treaty of friendship with the Emperor of the southern sea (the British India Company). He was clear in his advice that Nepal should not launch military initiatives against them. Its preparedness should only be for defensive wars' (Nepal Law commission, 2018, pp. 9-10). Until 1989, India was the primary armorer to Nepal but the 1988 arms purchase issues with China, and King
Birendra's proposal of 'Nepal as the Zone-ofPeace'. However, the Indian establishment perceived this proposal as the unstated purpose of the plan to extricate Nepal from its security obligations to India assumed under the treaty of 1950 (Garver, 1991, pp. 958-963). Thus, New Delhi not only failed to endorse the Zone-of-Peace proposal but also unofficially imposed the economic embargo in 1989 in order to pressure King Birendra Bikram Shah and his government to withdraw the arm purchase deal and to sign new treaty on trade and transit (ibid). This is the one representative instance of the geopolitical sensitivity of Nepal.

After the abolition of the Monarchy, the international regime has portrayed the NA as one of the most stable states bearing institutions in Nepal because of which, the involvement of the foreign actors in the name of military assistance is contending in Nepal. Among them, China, India and USA were seen in forefront. The recent engagement of international actors in other security agencies sounds interesting. Some of the representative cases include Chinese government's investment in APF Training Academy and the Indian government's support in Nepal Police Training Academy.

This global interest in Nepal certainly influences its CMR on the one hand and the national security on the other. Traditionally, the COAS of the NA is the Honorary General of the Indian Army, and the COAS of India is that of Nepal. Further, the geopolitical interplay in Nepal can easily be analyzed by the recent dilemma on the participation of the Nepali Army in the Bay of Bengal. Initiatives for Multi-Sectoral Technical and Economic Cooperation (BIMESTEC) level 
military drill, hosted by India ${ }^{7}$. Likewise, the Indo Pacific Strategy Report of Department of Defense, the US has included about the defense partnership with Nepal along with other South Asian countries, such as Maldives, Sri Lanka and Bangladesh in its Indo-Pacific strategy. It is clear that, geo-strategic location of Nepal is important and Nepal has to decide cautiously on Belt and Road Initiatives (BRI) led by China and Indo-Pacific strategy led by USA in the days to come. Otherwise, country may enter into other forms of instability.

\section{Conclusion}

CMR in Nepal is dynamic, not static, and unique in terms of understanding and practices. It has direct impact of regime changes and other subsequent political movements. At some point, the Nepali Army was under the control of palace and it was fully controlled by King ever since the modern nation -state formulation to 2005 . But after the 1990's political transformation, civilian came up with the antagonistic behavior towards the NA until 2008. After the Katuawal case in 2009, the Nepali Army is commonly perceived as the ultimate guarantor of sovereignty, territorial integrity, national unity and independence. Reviewing the documents and interacting with people, it has clearly shown that military was always under the control of civilian institutions in Nepal. However, to be effective civilian

7 Regarding this incidence, the spokesperson of NA highlighted that the army has to be abide by the decision of the government. At first ministry of defense has decided to participate in joint military drill and three NA officers were already there meanwhile the government withdraws its decision and NA participated as observer, interview on 4 November, 2018 control, political leadership must be aware of its importance as core aspect of CMR and national security, and military should cope with the aspiration of the peoples simultaneously. But the unwillingness of the political leadership to own the Nepali Army, and their reluctance in demarcating the roles and responsibilities of law enforcement agencies not only ruins the civil-military relations but also deteriorates the national security and national stability at large. Furthermore, the geopolitical sensitiveness of Nepal demands the farsighted creative state craft in terms of balancing CMR as well as foster national interests and national security. Therefore, the sharing of the responsibilities among the civilians and the military spheres can be effective solution to balance the CMR in Nepal.

\section{References}

Acharya, N. (2009). The Nepalese Army. In Sapkota, B. (Eds) (2009). The Nepali security sector: An almanac. Hungary: Brambauer Publishing.

Adhikari, I. (2015). Military \& democracy in Nepal. New Delhi: Routledge.

Asian Study Center for Peace and Conflict Transformation (ASPECT) (2011). From conflict to peace in Nepal: Peace agreements 2005- 2010. Kathmandu: ASPECT.

Basnyat, S. P. (2018). A soldier's cry: Chronicles of vices against national security of Nepal. Kathmandu: Hisi Offset Printers.

Bland, D. L. (1999). A Unified Theory of civilmilitary relations. Armed Force and Society, 26 (1), 7-26. 
Born, H., Fluri, P. \& Lunn, S. (Ed.). (2010). Oversight and guidence: The relevance of parliamentary oversight for the security sector. Geneva: Geneva Centrefor the Democratic Control of the Armed Forces (DCAF).

Bruneau, T. C., Matei, F. C. \& Sakoda, S. (2009). National security councils: Their potential functions in democratic civil-military relations. Defense and Security Analysis, 25 (3), 255-269.

Bruneau, T.C. \& Tollefson, S. D. (Ed.). (2006). Who guards the guardians and how:democratic civil military relations? Austin: University of Texas Press.

Desch, M. C. (2001). Civilian control of the military: The changing security environment. Baltimore: The Johns Hopkins University Press.

Feaver, P. D. (2003). Armed servents: Agency, oversight \& civil military relations. Cambridge: Harvard University Press.

Garver, J. W. (1991). China-India rivalry in Nepal: The clash over Chinese arms sales. Asian Survey, 31 (10), 956-975.

Gautam, K. C. (2009). The rehabilitation \& integration of Maoist combatants as part of Nepal's security sector reforms. In Bhattarai, R., \& Cave, R. (Ed.). (2009). Changing security dynamics in Nepal: A collection of essays. Kathmandu: Nepal Institute for Policy Studies and Saferworld.

Giraldo, J. K. (2006). Legislatures \& national defense: Global comparisons. In Bruneau,T. $\mathrm{C}$ and Tollefson, S.D. (Ed.) (2006). Who guards the guardians and how: Democratic civil-military relations? Austin: University of Texas Press.

Government of Nepal. (2016). National security policy. Ministry of Defense. Kathmandu: Singhadurbar. Retrieved from www.mod.gov. np on 5 October, 2018.
Government of Nepal. (2015). The constitution of Nepal. Retrieved from http://www. lawcommission.gov.np/en/archives/category/ documents/prevailing-law/constitution/ constitution -of-nepal, on 9 October, 2018.

Government of Nepal. (2006). Military act. Retrieved from http://www.lawcommission. gov.np/np/Military\%20Act, \%202006\%20 English.pdf, on 20 October, 2018.

Government of Nepal (2007). Interim constitution of Nepal. Retrieved from http://www. lawcommission.gov.np/np/archives/category/ documents/law-archives/constitution-lawarchives, on 5 October, 2018.

Government of Nepal. (1990). The constitution of kingdom of Nepal. Retrieved from http://www. lawcommission.gov.np/np/archives/category/ documents/law on November, 2018.

Huntington, S. P. (1957). The soldier and the state: The theory and politics of civil military relations. Boston: Harvard University Press.

Janowitz, M. (1960). The professional soldiers. New York: The Free Press.

Kumar, D. (2009). Democratic control of security forces. In Bhattarai, R, and Cave, R. (Ed.). (2009). Changing security dynamics in Nepal: A collection of essays. Kathmandu: Nepal Institute for Policy Studies and Saferworld.

Kummel, G. (2002). The military and its civilian environment: Reflections on a theory of civilmilitary relations. Connections, 1(4), 63-82.

Nepal Law Commission.. (2018). Celestial advice (Dibbaya Upadesh). Retrieved from http:// www.lawcommission.gov.np/en/wp-content/ uploads/2018/09/dibbaya-upadesh-oprithivi narayan-shah.pdf on November, 2018.

Schiff, R. L. (2001). The military and domestic politics: A concordance theory of civil-military relations. Routledge Military Studies. 
Sharma, S. (Ed.). (2010). Nepal Army: The challenges of civilian Ccontrol (Nepali Sena: Nagarik Niyantranka Chunauti). Kathmandu: Martin Chautari.

Sharma, J. \& Thapa, G. B. (2010). Democracy building and changing role of the Nepal Military. The Indian Journal of Political Science, 71(3), 969-994.

UNDP. (2009). The interim constitution of Nepal (2007). Second Edition. Retrieved from http://himalaya.socanth.cam.ac.uk/ collections/rarebooks/downloads/Nepal Interim_Constitution_2007_first_to_sixth amendements.pdf on 5 October, 2018.
Wagle, G. S. (2009). National security policy and role of national security council. In Bhattarai, R., and Cave, R. (Ed.). (2009). Changing security dynamics in Nepal: A collection of essays. Kathmandu: Nepal Institute for Policy Studies and Saferworld. 